\title{
Nutritional Composition and Fatty Acid Profile of Commercially Important Mullet Species in the Köyceğiz Lagoon
}

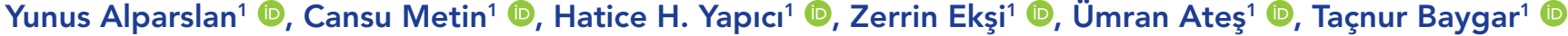

Cite this article as: Alparslan, Y., Metin, C., Yapici, H. H., Eksi, Z., Ates, U., Baygar, T. (2019). Nutritional composition and fatty acid profile of commercially important mullet Species in the Köyceğiz Lagoon. Aquatic Sciences and Engineering, 34(4), 131-137.

ORCID IDs of the authors: Y.A. 0000-0002-8833-996X: C.M. 0000-0002-2290-1489; H.H.Y. 0000-0001-5868-436X; Z.E. 0000-0001-7268-6169; Ü.A. 0000-0001-9756-1717;

T.B. 0000-0001-8070-0653

${ }^{1}$ Mugla Sitki Kocman University, Department of Seafood

Processing Technology, Mugla, Turkey

Submitted:

30.07.2019

Revision Requested:

19.09.2019

Last Revision Received: 20.09.2019

Accepted:

20.09.2019

Online published:

07.10.2019

Correspondence:

Yunus Alparslan

E-mail:

yunusalparslan@mu.edu.tr

(C) Copyright 2019 by Aquatic

Sciences and Engineering

Available online at

https://dergipark.org.tr/ase

\begin{abstract}
The present study is aimed to detect the nutritional composition and fatty acids profile of two different Mullet species caught from the/a fish barrier in Köyceğiz Lagoon (Muğla, Turkey) over a period of 12 months. A nutritional composition (protein, lipid, moisture and ash) and fatty acids profile were carried out for each commercially important mullet species; Mugil cephalus and CheIon saliens using standard measurement methods and gas chromatography (GC), respectively. The nutritional composition of the species showed differences depending on the harvesting and spawning seasons. Two mullet species had the highest fat content $(P<0.05)$ in spawning time, while moisture content was low $(\mathrm{P}<0.05)$ during the same period. Predominant fatty acids for two different mullet species were myristic acid, palmitic acid and stearic acid as saturated (SFA); palmitoleic acid, oleic acid and cis-11-eicosenoic acid as monounsaturated fatty acids (MUFAs); linoleic, cis-8, 11, 14- eicosatrienoic, eicosapentaenoic acid (EPA) and docosahexaenoic acid (DHA) as polyunsaturated fatty acids (PUFAs). The nutritional and fatty acid composition content of species varied due to the harvesting season, reproduction period and age of the fish. The results exhibited that mullet species during the reproductive period have higher lipid content and fatty acid composition, especially in terms of EPA and DHA.
\end{abstract}

Keywords: Mullet species, nutritional composition, fatty acids profile, EPA, DHA

\section{INTRODUCTION}

Fish and seafood are most important source of animal protein and are consumed all around the world due to its high protein, amino acid and unsaturated fatty acid content. It is an essential nutritional source for human diet (Suvitha et al., 2014). Fish oil contains $15-20 \%$ saturated and $80-85 \%$ unsaturated fatty acids. The two major classes of polyunsaturated fatty acids (PUFAs) are the n-3 and n- 6 fatty acids. Fish oils are known to be the main source of polyunsaturated fatty acids especially EPA and DHA (Schmidt et al., 2005). These fatty acids play an important role in human health, especially for nutrition, disease prevention and health promotion (Simopoulos, 2004) and are of great importance to humans for prevention of cardio- vascular disease, inflammatory response and autoimmune disorders (Leaf et al., 2003). Long chain n-3 PUFA cannot be synthesized by humans and must be obtained through diet (Alasalvar et al., 2002).

Lipids are important components in fish and seafood product for human diets, both as energy and fatty acids (FA) sources (Sargent et al., 2002). It is known that the amounts of fat and fatty acids of the same species or different species are influenced by various factors such as environmental conditions (water temperature, salinity), sex, age, size, season, feeding habits, abundance of food, life stage, migration, spawning period and etc. (Mısır et al., 2013). The biochemical compositions of fish are closely associated with these factors (Chaouch et al., 
2003). Köyceğiz Lagoon, located in the Mediterranean, is an important touristic area with its geomorphology and ecological variation. Lake Köyceğiz was declared as Köyceğiz-Dalyan Specially Protected Environmental Area (SPEA) in 1988 (Tosunoglu \& Saygi, 2018). In Köyceğiz Lagoon, a total of 50 fish species were identified in different studies (Buhan, 1998). In the lagoon, Akın et al. (2005) reported that eighteen species were determined in trammel net samplings. Much research reported that five mullet species Mugil cephalus, Liza aurata, Liza saliens, Liza ramada and Chelon labrosus were detected in Köyceğiz Lagoon barrier traps (Yerli, 1992; Buhan, 1998; Akın et al., 2005). It is commonly preferred and consumed by all economic group of people and it is also considered as low cost seafood (Kumaran et al., 2012). Besides been marketed as a fresh product, their eggs are processed and economically important products for people living around the lagoons.

The aim of this work was to investigate the proximate differences of the fish from two different genus that enter the same lagoon to spawn. In this context, the current study aims to evaluate the nutritional composition and the fatty acids profiles of two mullet species harvested from Köyceğiz Lagoon (Muğla, Turkey) throughout the 12 month period of and compare the differences among the fish harvested in the same habitat to spawn.

\section{MATERIALS AND METHODS}

\section{Fish samples}

Each commercially important mullet species; M. cephalus and C. saliens harvested from Köyceğiz Lagoon in Muğla city were used as study materials. Samples were obtained from DALKO Fisheries Cooperative who harvested the fish from fishing traps in the lagoon for 12 months, between July of 2015 and June of 2016. For each trial group, 10 individuals of different mullet species were chosen. A total of 100 fish of both species were used during the study. Flesh fish samples were packed into an insulated polystyrene box with ice and immediately transported to the Seafood Processing Laboratory in the Fisheries Faculty at Muğla Sıtkı Koçman University, within 2 hours of harvesting. After the biometric measurements of the fish brought to the laboratory, the fish were gutted and filleted before the assays. The fish meat was homogenized and analyzed. These processes were repeated for each fish sample from each species. Study was carried out for 12 months depending on the harvesting yield from lagoons.

\section{Nutritional composition analysis}

The mullet samples were analyzed in triplicate for nutritional composition (5 samples from 2 fish species): the total lipid content (\% wet weight) of $5 \mathrm{~g}$ homogenized raw edible parts of fish meat samples were determined by the chloroform/methanol extraction gravimetric method described by Bligh and Dyer (1959). The moisture contents (\% wet weight) of 3-5 g homogenized raw edible parts of fish meat samples were determined for all samples by drying for 3 hours at $105^{\circ} \mathrm{C}$ as described in the official method of the AOAC, 934.01 (2006). The ash content (\% wet weight) of the moisture free samples were determined using the official AOAC method 920.153 by ashing for $4-6$ hours at $550^{\circ} \mathrm{C}$ (AOAC, 2002). The total crude protein (\% wet weight) of $1 \mathrm{~g}$ homogenized raw edible parts of fish meat samples was analyzed by means of the Kjeldahl method 984.13 (AOAC, 2006a).

\section{Fatty acids methyl esters (FAME) analyses}

The methyl esters of lipid extracted was prepared by trans methylation using $2 \mathrm{M} \mathrm{KOH}$ in methanol and isooctane according to the method described by Ichihara et al. (1996) with minor modification; $25 \mathrm{mg}$ of extracted oil were dissolved in $2 \mathrm{ml}$ isooctane, followed by $4 \mathrm{ml}$ of $2 \mathrm{M} \mathrm{KOH}$ in methanol. Then, the tube was vortexed for $2 \mathrm{~min}$ at room temperature. After centrifugation at $4000 \mathrm{rpm}$ for $10 \mathrm{~min}$, the isooctane layer was taken for Gas chromatography analyses.

\section{Gas chromatography (GC) conditions}

The fatty acid methyl esters were analyzed using Gas chromatograph of Agilent Technologies model 7820 equipped with a flame ionization detector (FID) and fitted with a HP-88 capillary column (60 m x $0.25 \mathrm{~mm} \times 0.25 \mu \mathrm{m}$ thickness). Helium was used as the carrier gas at a constant pressure of 16 psi. Injection port was maintained at $220^{\circ} \mathrm{C}$, and the sample was injected in split mode with a split ratio of 50:1. Detector temperature was $280^{\circ} \mathrm{C}$. Column temperature was started at $175^{\circ} \mathrm{C}$, and then programmed at $3^{\circ} \mathrm{C} / \mathrm{min}$ to $220^{\circ} \mathrm{C}$, ramped at $1^{\circ} \mathrm{C} / \mathrm{min}$ to $220^{\circ} \mathrm{C}$, and held for $10 \mathrm{~min}$. The total running time was 26 minutes. Helium was used as the makeup gas at a constant flow of $40 \mathrm{~mL} / \mathrm{min}$, and hydrogen and dry air were used as detector gases (ISO 1990). Identification of fatty acids was carried out by comparing sample FAME peak relative retention times with those obtained for Supelco standards (Supelco 37 Compounds FAME mix $10 \mathrm{mg} / \mathrm{ml}$ in $\mathrm{CH}_{2} \mathrm{Cl}_{2}-47885 \mathrm{U}$, Supelco 1819-1 Ampule FAME mix C4-C24). Results of each fatty acids were expressed as FID response area relative percentages of the total fatty acids determined (ISO, 1990).

\section{Statistical analyses}

All experiments were carried out in triplicate and the results are reported as the mean and standard deviation of these measurements. Statistics on a completely randomized design were performed with the analysis of variance (ANOVA) procedure in SPSS (Version 21, SPSS Inc., Chicago, IL, USA) software. Tukey's multiple range test $(P<0.05)$ was used to detect differences among mean values of all test intervals.

\section{RESULTS AND DISCUSSION}

\section{Biometric parameter properties of mullet samples}

Biometrical parameters of two mullet species were shown in Table 1. A statistically significant relationship was found between lengths and weights of the fish of the same species depending on the month $(P<0.05)$. It was determined that the mean length and weight of $M$. cephalus were higher than the C. saliens.

\section{Nutritional composition analysis results}

Monthly changes in nutritional composition of $M$. cephalus, and C. saliens was shown in Table 2. Protein content of $M$. cephalus was found between $18.18 \%$ and $22.53 \%$ throughout the study. The highest protein content was observed in August. Lipid contents were found to be high in May, June and July while they were low in August and September. The highest moisture and ash value were obtained in September $(77.86 \%$ and $1.83 \%$, respectively). 
Table 1. The biometric parameters of two mullet species.

\begin{tabular}{|c|c|c|c|c|}
\hline Months & \multicolumn{2}{|c|}{ M. cephalus } & \multicolumn{2}{|c|}{ C. saliens } \\
\hline May & $33.45 \pm 6.10^{b}$ & $364.77 \pm 187.52^{b}$ & $30.75 \pm 2.08^{a}$ & $270.03 \pm 59.95^{\mathrm{a}}$ \\
\hline July & $35.08 \pm 4.74^{a}$ & $427.41 \pm 185.59^{a}$ & $30.58 \pm 1.51^{a}$ & $208.68 \pm 32.50^{b}$ \\
\hline August & $32.38 \pm 4.58^{c}$ & $314.31 \pm 149.79 c$ & $30.73 \pm 2.61^{a}$ & $213.32 \pm 53.25^{b}$ \\
\hline
\end{tabular}

Table 2. Changes of nutritional composition of mullet species.

\begin{tabular}{|c|c|c|c|c|}
\hline & \multicolumn{4}{|c|}{ M. cephalus } \\
\hline May & $18.18 \pm 0.08^{D}$ & $4.03 \pm 0.05^{A}$ & $73.58 \pm 0.18^{c}$ & $1.36 \pm 0.03^{c}$ \\
\hline June & $21.49 \pm 0.15^{\mathrm{B}}$ & $3.67 \pm 0.22^{\mathrm{AB}}$ & $74.67 \pm 0.26^{B}$ & $1.42 \pm 0.02^{\mathrm{B}}$ \\
\hline July & $20.72 \pm 0.53^{c}$ & $3.41 \pm 0.29^{B}$ & $74.67 \pm 0.65^{\mathrm{B}}$ & $1.33 \pm 0.10^{c}$ \\
\hline August & $22.53 \pm 1.40^{\mathrm{A}}$ & $1.37 \pm 0.28^{c}$ & $77.46 \pm 0.21^{\mathrm{A}}$ & $1.34 \pm 0.51^{c}$ \\
\hline May & $17.39 \pm 0.02^{\mathrm{B}}$ & $4.19 \pm 0.03^{B}$ & $75.27 \pm 0.46^{B}$ & $1.42 \pm 0.12^{\mathrm{A}}$ \\
\hline July & $18.07 \pm 1.31^{\mathrm{B}}$ & $5.48 \pm 0.06^{A}$ & $73.10 \pm 0.25^{c}$ & $1.25 \pm 0.12^{\mathrm{A}}$ \\
\hline August & $20.16 \pm 0.13^{\mathrm{A}}$ & $3.47 \pm 0.64^{c}$ & $76.61 \pm 0.64^{\mathrm{A}}$ & $1.32 \pm 0.04^{\mathrm{A}}$ \\
\hline
\end{tabular}

The highest protein and moisture content of $C$. saliens were detected in August (20.16 and $76.61 \%$, respectively), while highest lipid content $(5.48 \%)$ was in July $(P<0.05)$. There were no significant differences for ash content depending on months $(P>0.05)$. It has been observed that there is an inverse correlation between the ratio of lipid to the moisture content of all mullet species. The results of the nutritional composition analyses revealed that there were significant differences in protein, moisture and lipid contents for two mullet species except for the ash content which are thought to be related to the harvesting season $(P<0.05)$. The nutritional composition of fish was highly dependent on a number of factors, namely catching months, environmental conditions, geographical regions, age, and fish diets. The high ash content obtained indicates that all these fish are rich in minerals (Tenyang et al., 2016). This inverse relationship between moisture and lipid content has been reported for sea bream (Sparus aurata) and sea bass (Dicentrarchus labrax) (Grigorakis, 2007). Özogul and Özogul (2007) investigated that lipid content of M. cephalus is $2.09 \%$. In another study from Bangladesh, moisture, ash, protein and lipid contents of $M$. cephalus were reported as 70.83, 1.7, 21.38 and $6.12 \%$, respectively (Azam et al., 2004). In the study which investigated the microbiological and nutritional character of processed $M$. cephalus, the moisture content of fresh samples was determined as $71.91 \%$, protein content $18.48 \%$ and lipid content $8.44 \%$ (Mostafa \& Salem 2015). Khitouni et al. (2014) de- termined the water content of $L$. aurata species obtained from Tunisian coast and found that they were in the range of 64.86$77.68 \%$ in male specimens and $63.77-77.89 \%$ in females. They also found the annual lipid; protein; ash content mean for male and female specimens as $4.58 \%$ and $5.09 \%$; $19.93 \%$ and $20.20 \%$; $1.56 \%$ and $1.59 \%$, respectively.

The lower lipid content of mullet species from Köyceğiz Lagoon may be due to the gonadal maturation because it was caught off during its spawning migration, which occurs at different times for each mullet species. There is a widespread decrease in the amount of whole body fat in many fish species, especially in the spawning period (Khitouni et. al., 2014).

\section{Fatty acid profile of mullet samples}

Fatty acid profile of $M$. cephalus were shown in Table 3. Miristic, palmitic and stearic acid as saturated fatty acids (SFA); palmitoleic (C16:1), oleic and cis-11-eicosenoic acid as mono unsaturated fatty acids (MUFA); linoleic, cis-8-11-14-eicosatrienoic, EPA and DHA as poly unsaturated fatty acids (PUFA) were detected as major fatty acids. EPA content was higher in May and June when compared to other months. Similarly, DHA content was higher in September and August $(P<0.05)$. The highest total SFA (34.61\%) and PUFA (33.70\%) were obtained in September, while the highest MUFA (21.84\%) was obtained in June. 
Table 3. Fatty acid profile (expressed as percentage of total fatty acids) in raw edible parts of $M$. cephalus.

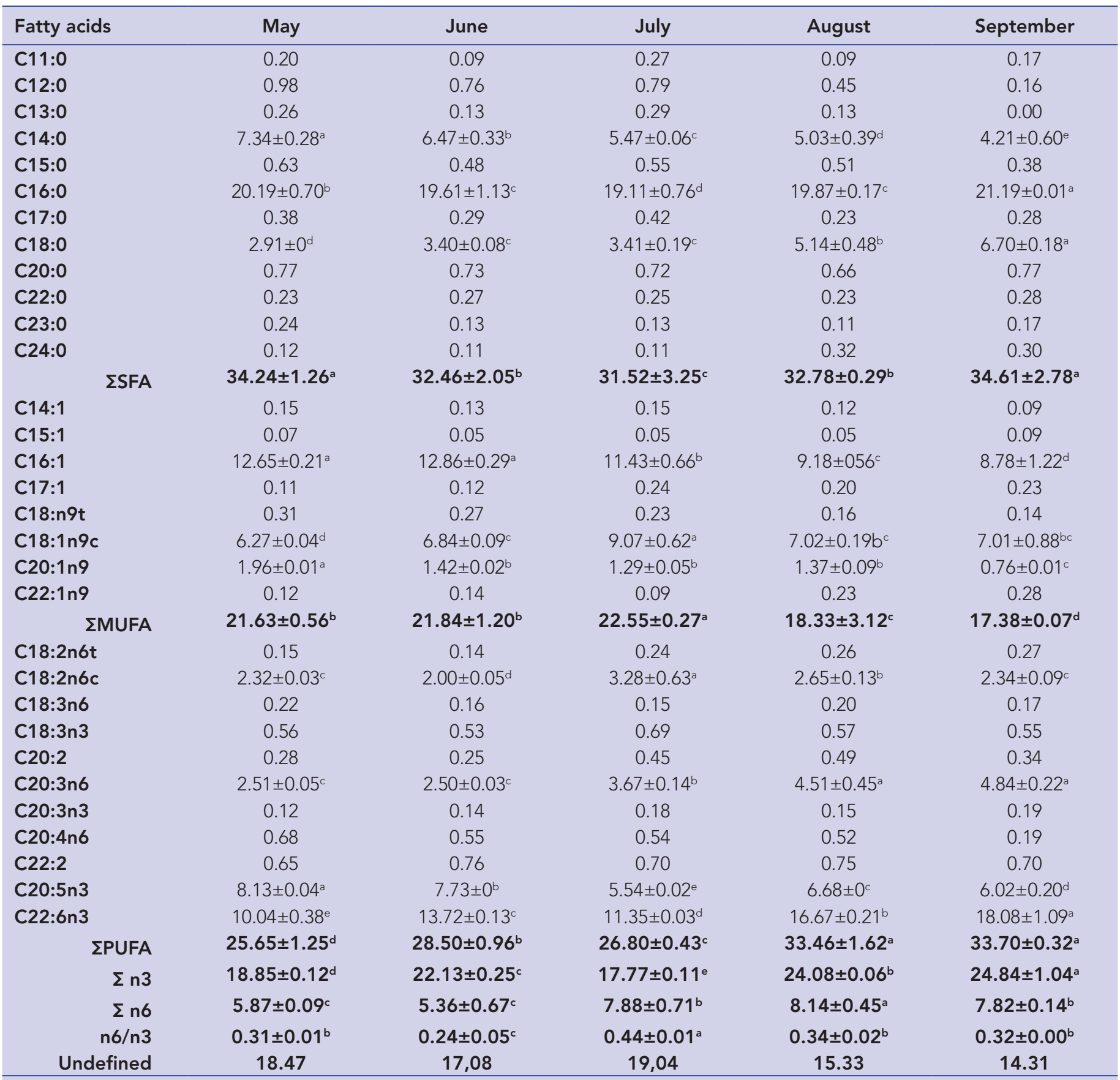

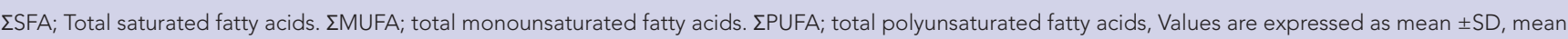
values in row with different superscripts were significantly different $(P \leq 0.05)$ between the months.

Özogul and Özogul (2007) found the total MUFA and PUFA ratios of the M. cephalus samples as 25.8 and $24.8 \%$, respectively. The most abundant fatty acid was palmitic acid (C16: 0 ) as $21.5 \pm 0.33$ (\%). They also determined DHA as 7.69 and EPA as $10.5 \%$ (42\% of the total PUFA). Mostafa and Salem (2015) reported that palmitic acid, oleic acid and linoleic acid were identified as the major fatty acids for processed M. cephalus.
El-Sherif and El-Ghafour (2016) who investigated the nutrient composition and fatty acid content of four important fish species (Tilapia zilii, Solea vulgaris, Metapenaeus stebbing and M. cephalus) in Lake Quarin, determined the moisture, protein, lipid and ash content of $M$. cephalus as $74.85 \pm 0.45,19.10 \pm 0.15,4.48 \pm 0.09$ and $1.33 \pm 0.32 \%$ respectively. Dominant fatty acids were palmitic acid (C16:0) as SFA, oleic acid (C18:1 n-9cis) as MUFA and DHA (C22:6 n-3) as PUFA. Kumaran et al. (2012) found lipid, protein, 
Table 4. Fatty acid profile (expressed as percentage of total fatty acids) in raw edible parts of C. saliens.

\begin{tabular}{|c|c|c|c|}
\hline Fatty acids & May & July & August \\
\hline C11:0 & 0.02 & 0.08 & 0.08 \\
\hline C12:0 & 0.12 & 0.33 & 0.31 \\
\hline C14:0 & $4.42 \pm 0.02^{c}$ & $6.94 \pm 0.06^{b}$ & $7.40 \pm 0.08^{a}$ \\
\hline C15:0 & 0.44 & 0.41 & 0.46 \\
\hline C16:0 & $20.10 \pm 0.20^{a}$ & $17.49 \pm 0.41^{b}$ & $20.31 \pm 0.09^{a}$ \\
\hline C18:0 & $3.12 \pm 0.04^{a}$ & $2.64 \pm 0.05^{b}$ & $3.12 \pm 0.03^{a}$ \\
\hline C20:0 & 0.64 & 1.15 & 1.21 \\
\hline C22:0 & 0.21 & 0.33 & 0.33 \\
\hline C23:0 & 0.17 & 0.16 & 0.16 \\
\hline C24:0 & 0.08 & 0.09 & 0.12 \\
\hline C16:1 & $16.39 \pm 0.35^{a}$ & $14.91 \pm 0.11^{b}$ & $16.06 \pm 0.07^{a}$ \\
\hline C17:1 & 0.10 & 0.21 & 0.04 \\
\hline C18:n9t & 0.31 & 0.19 & 0.17 \\
\hline C18:1n9c & $9.15 \pm 0.60^{a}$ & $8.41 \pm 0.31^{b}$ & $7.14 \pm 0.08^{c}$ \\
\hline C20:1n9 & $1.47 \pm 0.04^{b}$ & $1.69 \pm 0.03^{a}$ & $1.26 \pm 0.01^{c}$ \\
\hline C22:1n9 & 0.05 & 0.11 & 0.22 \\
\hline ¿MUFA & $27.62 \pm 0.97^{a}$ & $25.57 \pm 1.45^{b}$ & $24.82 \pm 1.99^{b}$ \\
\hline C18:2n6t & 0.16 & 0.12 & 0.28 \\
\hline C18:2n6c & $2.04 \pm 0.01^{c}$ & $3.81 \pm 0.04^{a}$ & $3.11 \pm 0.01^{b}$ \\
\hline C18:3n6 & 0.09 & 0.16 & 0.17 \\
\hline$C 20: 5 n 3$ & $8.33 \pm 0.04^{a}$ & $7.50 \pm 0^{b}$ & $7.01 \pm 0.16^{c}$ \\
\hline$C 22: 6 n 3$ & $9.38 \pm 0.18^{b}$ & $10.68 \pm 0.12^{\mathrm{a}}$ & $9.49 \pm 0.10^{b}$ \\
\hline 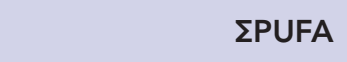 & $25.73 \pm 1.01^{b}$ & $27.89 \pm 2.15^{a}$ & $25.38 \pm 0.82^{b}$ \\
\hline$\sum n 3$ & $18.29 \pm 0.15^{b}$ & $18.91 \pm 0.01^{a}$ & $17.21 \pm 0.02^{c}$ \\
\hline$\sum n 6$ & $6.64 \pm 0.50^{c}$ & $7.99 \pm 0.04^{a}$ & $7.42 \pm 0.17^{b}$ \\
\hline n6/n3 & $0.36 \pm 0.02^{b}$ & $0.42 \pm 0.00^{a}$ & $0.43 \pm 0.01^{a}$ \\
\hline Undefined & 16.91 & 16.42 & 15.55 \\
\hline
\end{tabular}

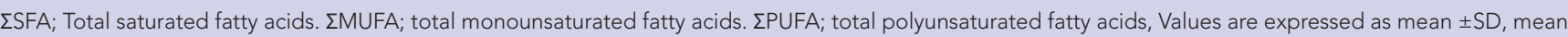
values in row with different superscripts were significantly different $(P \leq 0.05)$ between the months.

ash content of M. cephalus in India Parangipattai coastal waters as $2.42,17.56,1.15 \%$, respectively. The fatty acid composition was found as SFA 40.24\%, MUFA 33.48\%, PUFA 26.28\%. Bayır et al. (2006) studied the fatty acid composition of 12 fish species harvested from Turkish seas. They reported that EPA and DHA value of $M$. cephalus as $8.7 \pm 0.84 \%$ and $22.7 \pm 1.61 \%$, respectively. Şen (2006) seasonally investigated the total fatty acid composi- tion of M. cephalus from Mersin. It was concluded that total PUFAs ratio were found higher than SFAs ratio for all seasons. However, the highest fatty acid was found to be palmitic as SFA and $\mathrm{n}-6$ amount was determined to be higher than $\mathrm{n}-3$.

Fatty acid composition results of $C$. saliens as shown in Table 4. Similar to M. cephalus and L. aurata, miristic, palmitic and stearic acid as saturated fatty acids (SFA); palmitoleic, oleic and cis-11-ei- 
cosenoic acid as mono unsaturated fatty acids (MUFA); linoleic, cis-8-11-14-eicosatrienoic, EPA and DHA as poly unsaturated fatty acids (PUFA) were detected as major fatty acids. EPA content was determined to be higher in May and DHA content was determined to be higher in July when they were compared with other months $(P<0.05)$. The highest total SFAs were determined in August (33.88\%) while the highest MUFAs (27.62\%) and PUFAs (27.89\%) were in May and July, respectively.

Kamdem et al. (2008) who investigated some safety indices (presence of pathogenic microbial species, heavy metal and biogenic amine concentrations) and nutritional content (percent composition and fatty acid profile) of L. ramada, L. aurata and L. saliens species reported that palmitic acid (C16:0) as SFAs was 13.27\% for L. saliens, $13.56 \%$ for L. aurata; palmitoleic acid (C16:1 n-7) as MUFA was $19.48 \%$ for $L$. saliens and $25.38 \%$ for $L$. aurata. They also reported that $n 3 / n 6$ ratio of $L$. aurata and $L$. saliens for PUFAs was 3 times lower in L. saliens. In a different study, the amount of total saturated, monounsaturated and polyunsaturated fatty acids for $L$. saliens from Mediterranean coastal lagoons were $43.5,33.7,22.8 \%$, respectively while EPA and DHA values were 4.9 and $2.4 \%$, respectively (Koussoroplis et al., 2011).

While the total SFA value of the $M$. cephalus was found to be higher than the $C$. saliens $(P<0.05)$. These fatty acids are a potential source of metabolic energy in fish, especially in terms of growth and gonad development in female fish. The lowest amount of $\mathrm{C} 16: 0$ in the flesh total lipids was detected for L. aurata during spawning time, which apparently corresponded to the changes in C16:0 in dietary plankton lipids (Huynh et al., 2007). The most abundant MUFA was C16:1, C18:1n9 and C20:1n9 for two mullet species. In contrast to the total SFA value, the total MUFA value of $M$. cephalus species was found to be lower than the $C$. saliens species. These MUFAs have been associated with zooplankton and variation in the levels could reflect varying amounts of zooplankton consumed in the diet (Budge et al., 2002; Huynh et al., 2007). As a result, our findings showed that two mullets is a better source of PUFA, especially linoleic acid, eicosatrienoic acid, EPA and DHA. It was also observed that the proportion of these fatty acids changed significantly between species. These results are in agreement with previous studies on fatty acid of other species (Özogul \& Özogul, 2007; Tenyang et al., 2016).

The UK Department of Health recommends an ideal ratio of n6/ $\mathrm{n} 3$ of 4.0 at maximum (COMA, 1994). Values higher than the maximum value are harmful to health and may promote cardiovascular diseases (Moreira et al., 2001). In this study, the highest n6/n3 ratio for $M$. cephalus, and $C$. saliens was determined in July $(0.44$ $\%)$, and August $(0.43 \%)(P<0.05)$, respectively. The ratio of $n 6 / n 3$ was found at very low levels all mullet species. The data revealed that all mullet fish from Köyceğiz Lagoon were a good source of total $\omega-3$ PUFA ranging from $14.74 \%$ to $30.10 \%$. A good natural source of these fatty acids (especially EPA and DHA) is seafood (Calder \& Yaqoob, 2009). The total n3 amount was found to be highest in August and September for M. cephalus and in July for C. saliens. As in this study, the high $n-3$ value in fish species is very important for human health. If taken in an adequate amount, it helps prevent health problems such as serious cardiovascular diseases (Mayneris-Perxachs et al., 2010).

\section{CONCLUSIONS}

In the current study, the nutritional composition and fatty acid profile of mullet species that were caught in Köyceğiz lagoon located on the northwestern Turkish coast of Mediterranean were investigated periodically. In conclusion, this study revealed the fatty acid compositions of all mullet species in spawning and non-spawning period of mullet, which have not previously been studied in Köyceğiz Lagoon. The results showed that the nutritional composition of mullet species varies depending on the catching season. This might be due to changes in environmental conditions i.e., spawning and migration periods as well as age and sex of fish. Protein, lipid and fatty acid contents of mullet species were found to be significantly higher during reproduction periods. Our study figured out that lipid contents and fatty acid profiles of mullets vary with the life cycle and condition at maturity. We have shown that spawning mullet species exhibit a marked increase in the relative concentration of MUFA. On the contrary, the PUFA concentrations were remarkably higher after the spawning period. This might be due to the lipid storage of the fish body due to the long migration period that fish need to spend to find a place to spawn. Fish body prepares itself to spawn, so the fish losses its lipid content for storing eggs. So, fatty acid profile of the fish fillets may vary depending on the pre and after spawning time. Low lipid contents cause an undesirable meat quality, so mullets are not advised to be consumed as a good n-3 source just after their spawning period. The study results revealed out that all mullet species have strong nutritional value and may be suggested for intake of PUFA (long-chain n-3) especially EPA (20:5n-3) and DHA (22:6n-3).

Acknowledgements: Authors thanks to TUBITAK for supporting and Tuba Baygar for English editing and İsmail Reis for biometric parameter measurements.

Financial Disclosure: This study was supported by The Scientific and Technological Research Council of Turkey (TUBITAK) 1002-Short Term R\&D Funding Program with 1150839 project number.

Conflict of interest: The authors declare that they have no conflicts of interest.

\section{REFERENCES}

Alasalvar, C., Taylor, K. D. A., Zubcov, E., Shahidi, F. \& Alexis, M. (2002). Differentiation of cultured and wild sea bass (Dicentrarchus labrax): total lipid content, fatty acid and trace mineral composition. Food Chemistry, 79, 145-150. [CrossRef]

Akın, S., Buhan, E., Winemiller, K. O. \& Yılmaz, H. (2005). Fish assemblage structure of Köycegiz Lagoon Estuary, Turkey: Spatial and temporal distribution patterns in relation to environmental variation. Estuarine, Coastal and Shelf Science, 64(4), 671-684. [CrossRef]

AOAC (2002). Ash content. Official method 920.153. Official Methods of Analysis (17 th ed.). Gaithersburg: Maryland (USA): Association of Official Analytical Chemists.

AOAC (2006). Moisture content. Official method 934.01. Official Methods of Analysis (1 $17^{\text {th }}$ ed.). Gaithersburg: Maryland (USA): Association of Official Analytical Chemists.

AOAC (2006a). Crude protein in meat. Official method 984.13. Official methods of analysis, ([Revised] (18 $8^{\text {th }}$ ed.). Washington: DC. (USA): Association of Official Analytical Chemists. 
Azam, K., Ali, M. Y., Asaduzzaman, M., Basher, M. Z. \& Hossain, M. M. (2004). Biochemical assessment of selected fresh fish. Journal of Biological Sciences, 4(1), 9-10. [CrossRef]

Bayır, A., Haliloğlu, H. i., Sirkecioğlu, A. N. \& Aras, N. M. (2006). Fatty acid composition in some selected marine fish species living in Turkish waters. Journal of the Science of Food and Agriculture, 86(1), 163168. [CrossRef]

Bligh, E. G. \& Dyer, W. J. (1959). A rapid method of total lipid extraction and purification. Canadian Journal of Biochemistry and Physiology, 37(8), 911-917. [CrossRef]

Budge, S. M., Iverson, S. J., Bowen, W. D. \& Ackman, R. G. (2002). Amongand within-species variability in fatty acid signatures of marine fish and invertebrates on the Scotian Shelf, Georges Bank, and southern Gulf of St. Lawrence. Canadian Journal of Fisheries and Aquatic Sciences, 59(5), 886-898. [CrossRef]

Buhan, E. (1998). Development of Lagoon Management of Köyceğiz Lagoon System by Researching Present Situation and Grey Mullet Populations (in Turkish). Ministry of Agriculture and Rural Affairs, Bodrum Fishery Research Institute Press, Serial B, Publish No. 3, 347 pp.

Calder, P. C. \& Yaqoob, P. (2009). Understanding omega-3 polyunsaturated fatty acids. Postgraduate medicine, 121(6), 148-157. [CrossRef]

Chaouch, A., Bouhlel, I., Chraief, I., Hammami, M., El Hani, A., Romdhane, M. S. \& El Cafsi, M. (2003). Seasonal variation of polyunsaturated fatty acids ( $n-3)$ composition in Diplodus annularis from the gulf of Tunis: nutritional benefits. Journal-Societe Chimique De Tunisie 5(1), 55-64.

COMA (1994). Nutritional aspects of cardiovascular disease. Committee on Medical Aspects of Food Policy, Report No. 46, HMSO, London.

El-Sherif, S. A. E. H. \& El-Ghafour, S. A. (2016). Investigation of the quality properties and nutritional values of four fish species from Lake Qaroun, Egypt. International Journal of ChemTech Research, 9(4), 16-26.

ISO (1990). Animal and vegetable fats and oils-Analysis by gas chromatography of methyl esters of fatty acids, EN ISO 5508.

Grigorakis, K. (2007). Compositional and organoleptic quality of farmed and wild gilthead sea bream (Sparus aurata) and sea bass (Dicentrarchus labrax) and factors affecting it: a review. Aquaculture, 272, 55-75. [CrossRef]

Huynh, M. D., Kitts, D. D., Hu, C. \& Trites, A. W. (2007). Comparison of fatty acid profiles of spawning and non-spawning Pacific herring, Clupea harengus pallasi. Comparative Biochemistry and Physiology Part B: Biochemistry and Molecular Biology, 146(4), 504-511. [CrossRef]

Ichihara, K. I., Shibahara, A., Yamamoto, K. \& Nakayama, T. (1996). An improved method for rapid analysis of the fatty acids of glycerolipids. Lipids, 31(5), 535-539. [CrossRef]

Kamdem, S. S., Vernocchi, P., Maffei, M., Belletti, N., Gardini, F., Guerzoni, M. E. \& Lanciotti, R. (2008). Assessment of safety, nutritional, and spoilage characteristics of different lagoon grey mullets (Liza ramada, Liza aurata, and Liza saliens). Journal of food protection, 71(12), 2572-2577. [CrossRef]

Khitouni, I. K., Mihoubi, N. B., Bouain, A. \& Rebah, F. B. (2014). Seasonal variations in proximate and fatty acid composition of golden grey mullet Liza aurata $(R, 1810)$ from the Tunisian coast. International Journal of Agricultural Policy and Research, 2(7), 273-280.

Koussoroplis, A. M., Bec, A., Perga, M. E., Koutrakis, E., Bourdier, G. \& Desvilettes, C. (2011). Fatty acid transfer in the food web of a coastal Mediterranean lagoon: Evidence for high arachidonic acid retention in fish. Estuarine, Coastal and Shelf Science, 91(3), 450-461. [CrossRef]
Kumaran, R., Ravi, V., Gunalan, B., Murugan, S. \& Sundramanickam, A. (2012). Estimation of proximate, amino acids, fatty acids and mineral composition of mullet (Mugil cephalus) of Parangipettai, Southeast Coast of India. Advances in Applied Science Research, 3(4), 20152019

Leaf, A., Kang, J. X., Xiao, Y. F. \& Billman, G. E. (2003). Clinical prevention of sudden cardiac death by n-3 polyunsaturated fatty acids and mechanism of prevention of arrhythmias by $n-3$ fish oils. Circulation, 107(21), 2646-2652. [CrossRef]

Mayneris-Perxachs, J., Bondia-Pons, I., Serra-Majem, L., Castello, A. I. \& López-Sabater, M. C. (2010). Longchain n-3 fatty acids and classical cardiovascular disease risk factors among the Catalan population. Food Chemistry, 119, 54-61. [CrossRef]

Mısır, G. B., Kutlu, S. \& Çibuk, S. (2013). Determination of total lipid and fatty acid composition of pearl mullet (Chalcalburnus tarichi, Pallas 1811). Turkish Journal of Fisheries and Aquatic Sciences, 13(5), $777-$ 783.

Moreira, A. B., Visentainer, J. V., de Souza, N. E. \& Matsushita, M. (2001). Fatty acids profile and cholesterol contents of three Brazilian Brycon freshwater fishes. Journal of Food Composition and Analysis, 14(6), 565-574. [CrossRef]

Mostafa, A. A. \& Salem, R. H. (2015). Characterization of microbiological and nutritional variations in processed mullet (Mugil cephalus) Fish. International Journal of Microbiological Research, 6(2), 108-122.

Özogul, Y. \& Özogul, F. (2007). Fatty acid profiles of commercially important fish species from the Mediterranean, Aegean and Black Seas. Food Chemistry, 100(4), 1634-1638. [CrossRef]

Sargent, J. R., Tocher, D. R. \& Bell, J. G. (2002). The lipids. In E. Halver and R.W. Hard (Eds.), Fish nutrition (pp: 181-257). London, UK: Academic Press. [CrossRef]

Schmidt, E. B., Arnesen, H., de Caterina, R., Rasmussen, L. H. \& Kristensen, S. D. (2005). Marine n-3 polyunsaturated fatty acids and coronary heart disease: Part I. Background, epidemiology, animal data, effects on risk factors and safety. Thrombosis Research, 115(3), 163-170. [CrossRef]

Simopoulos, A. P. (2004). Omega-6/omega-3 essential fatty acid ratio and chronic diseases. Food Reviews International, 20(1), 77-90. [CrossRef]

Suvitha, S., Eswar, A., Anbarasu, R., Ramamoorthy, K. \& Sankar, G. (2014). Proximate, amino acid and fatty acid profile of selected two Marine fish from Parangipettai Coast. Asian Journal of Biomedical and Pharmaceutical Sciences, 4(40), 38-42.

Şen, S. (2006). Seasonal variation of the total fatty acid composition of the mullet, Mugil cephalus L. 1758 (Osteichthyes: Mugilidae). Selçuk University, Institute of Science and Technology, Master thesis, Konya.

Tenyang, N., Ponka, R., Tiencheu, B., Womeni, H. M. \& Tonfack, F. (2016). Proximate composition, fatty acid and mineral contents of four freshwater fish from Maga Lake (Far North Region of Cameroon). American Journal of Food Science and Technology, 4(3), 64-69.

Tosunoglu, Z. \& Saygi, H. (2018). Analysis of long and short terms fishery landings of Köyceğiz Lagoon (Turkey). Turkish Journal of Fisheries and Aquatic Sciences, 19(3), 199-208. [CrossRef]

Yerli, S. (1992). Investigations on the stocks of Liza ramada (Risso, 1826) in Köyceğiz lagoon system (in Turkish). Doğa Turkish Journal of Veterinary and Animal Sciences, 16, 103-120. 